\title{
Bond strength of orthodontic brackets bonded to enamel with a self-etching primer after bleaching and desensitizer application
}

\author{
Nuray Attar, DDS, PhD, ${ }^{\text {a }}$ Yonca Korkmaz, DDS, PhD, ${ }^{\mathrm{b}}$ Yasemin Kilical, DDS, ${ }^{\mathrm{c}}$ \\ Banu Saglam-Aydinatay, DDS, PhD, ${ }^{\mathrm{d}}$ Ceren Ozge Bicer, DDS
}

\begin{abstract}
Objective: The aim of this study was to compare the shear bond strengths (SBS) of orthodontic brackets bonded to enamel with a self-etching primer after bleaching, desensitizer application and combined treatment. Methods: Forty-eight premolars were randomly divided into four groups, each with $n=12$ premolar samples. The four groups were; Group1: 15\% hydrogen-peroxide office bleaching agent (Illuminé Office-IO), Group 2: 10 + BisBlock Oxalate Dentin-Desensitizer, Group 3: Bis Block Oxalate Dentin-Desensitizer, Group 4: No treatment (control). Twenty-four hours after bonding, the specimens were tested in SBS at a crosshead speed of $5 \mathrm{~mm} / \mathrm{min}$ until the brackets debonded. The failure mode of the brackets was determined by a modified adhesive remnant index. Results: Bleaching, bleaching and desensitizer treatment, and desensitizer treatment alone all significantly reduced SBS of the orthodontic brackets $(p=0.001)$. No statistically significant difference was found between Group 1, Group 2 and Group 3 (Group 1-Group 2, $p=0.564$; Group 1-Group 3, $p=0.371$; Group 2-Group 3, $p=0.133$ ). The predominant mode of failure for the treatment groups (Group1, Group 2 and Group 3) was at the enamel-adhesive interface leaving $100 \%$ of the adhesive on the bracket base. Conclusions: Bleaching and desensitizer treatment should be delayed until the completion of orthodontic treatment. (Korean J Orthod 2010;40(5): 342-348)
\end{abstract}

Key words: Bracket, Adhesive, Bonding

\section{INTRODUCTION}

Bleaching is considered the most conservative and economical alternative for improving the appearance of discolored teeth. ${ }^{1}$ Vital tooth bleaching can be performed either in the dental office (office bleaching) or by the patient at home (home bleaching). ${ }^{2}$

Hydrogen peroxide and carbamide peroxide solutions are widely used as a bleaching agent. The ability of these products to lighten the color is clear but the safety of these bleaching agents is a cause for concern. Pulpal and gingival irritation, ${ }^{3}$ changes in salivary $\mathrm{pH}^{4}$, alterations in enamel surface morphology, ${ }^{5}$ adherence of streptococcus mutans to bleached enam$\mathrm{el},{ }^{6}$ alterations on composite resins, ${ }^{7}$ microleakage of restorations ${ }^{8}$ and changes in ultramorphological res- 
in-enamel interface ${ }^{9}$ were associated with these agents.

Dentin hypersensitivity or tooth sensitivity is characterized by short, sharp pain arising from exposed dentin in response to stimuli such as thermal, evaporative, tactile, osmotic, or chemical and which cannot be ascribed to any other form of dental defect or pathology. ${ }^{10}$ Dental professionals can initiate hypersensitivity treatment by educating the patient about dietary acids, other oral care habits, recommending different toothbrushing agents and a desensitizing agent for home use. Temporary pain that can sometimes result from bleaching treatment can also be treated by applying topical desensitizing agents professionally. ${ }^{11}$ The treatment mainly focuses on occluding the dentinal tubules by various precipitates or covering the exposed dentin with an impermeable layer to prevent the osmotic gradient changes that create the painful stimuli. ${ }^{12}$

Various types of resin bonding systems have been introduced to the dental market in the last decade. Today, dental adhesives can be divided into two in terms of simplified clinical applications. The first category includes a phosphoric acid etchant for enamel and a bottle of adhesive resin. The second category includes a self-etching primer, which combines the etching and priming in one procedure and an adhesive resin. $^{13,14}$

Self-etching adhesive systems, composed of aqueous mixtures of acidic functional monomers, which are generally phosphoric acid esters, do not require a sepa- rate acid etch component and subsequent rinsing procedure. $^{15-17}$ Acidic monomers partially dissolve the hydroxyapatite constituent, incorporating the smear layer into the demineralized dentin substrate (collagen fibers and resin monomers), while simultaneously infiltrating the collagen network with primers and eventual resin monomer attachment with consequential occlusion of the dentinal tubules and decreased levels of post-treatment sensitivity.

Transbond Plus Self Etching Primer (3M Unitek, Monrovia, CA, USA) is a self-etching adhesive developed for orthodontic bonding whose chemical formulation is similar to that of phosphoric acid although its solid matrix is formed by two chains. ${ }^{18}$ The same monomer that causes acid etching also allows primer penetration of the enamel with placement of the primer into the demineralization region at the same time. ${ }^{19}$

It is generally recommended that the patient waits for the end of orthodontic treatment before bleaching treatment. However, some patients may have already had at-home or office bleaching treatments before seeking orthodontic treatment. Therefore it is important to determine the relationship between bleaching treatment and bond strength of brackets.

The purpose of this in vitro study was to compare the shear bond strength (SBS) of orthodontic brackets bonded to human enamel with a self-etching primer after bleaching, desensitizer application and combined treatment.

Table 1. Manufacturers and types of the materials utilized in the study

\begin{tabular}{|c|c|c|c|}
\hline Products & Type & Composition & Manufacturer \\
\hline Illuminé & Office bleaching agent & $\begin{array}{l}\text { 30\% hydrogen peroxide, poly } \\
\text { (methyl vinyl ether/maleic } \\
\text { anhydride) mixed calcium/sodium } \\
\text { salts, titanium dioxide }\end{array}$ & $\begin{array}{l}\text { Dentsply, DeTrey, GmbH, } \\
\text { Konstanz, Germany }\end{array}$ \\
\hline BisBlock & Oxalate dentin desensitizer & Oxalic acid & $\begin{array}{l}\text { Bisco Inc, Schaumburg, IL, } \\
\text { USA }\end{array}$ \\
\hline Transbond Plus & Self-etching primer & $\begin{array}{l}\text { Fluoride, no filler, methacrylate } \\
\text { ester derivative }\end{array}$ & $\begin{array}{l}\text { 3M Unitek, Monrovia, CA, } \\
\text { USA }\end{array}$ \\
\hline Transbond XT & Light cure adhesive paste & $\begin{array}{l}\text { Quartz silica, Bis-GMA, bisphenol } \\
\text { A bis (2-hydroxyethyl ether) } \\
\text { dimetacrylate }\end{array}$ & $\begin{array}{l}\text { 3M Unitek, Monrovia, CA, } \\
\text { USA }\end{array}$ \\
\hline
\end{tabular}

Bis-GMA, Bis-phenol A diglycidylmethacrylate. 


\section{MATERIAL AND METHODS}

Manufacturers and types of the materials utilized in this study are presented in Table 1 . Forty-eight freshly extracted human permanent premolars without any caries or visible defect were used. The criteria for tooth selection included intact buccal enamel, no pretreatment chemical agents (eg, hydrogen peroxide), no cracks caused by the extraction forceps and no caries. The teeth were cleaned and then polished with pumice and rubber cups for 10 seconds and the roots were embedded in polymethyl methacrylate.

The teeth were randomly assigned to 4 groups. Each group consisted of 12 specimens. The four treatment groups were:

Group 1: Teeth were bleached with $15 \%$ hydrogen peroxide office bleaching agent (Illuminé Office, Dentsply, Konstanz, Germany) for 60 minutes. Before bonding, the teeth were stored in distilled water for two days at room temperature.

Group 2: Teeth were bleached in the same manner as Group 1, except that after bleaching and before bonding, desensitizer gel (BisBlock Oxalate Dentin Desensitizer; Bisco Inc., Schaumburg, IL, USA) was used. For the desensitizer application, the following procedures were performed: the teeth samples were etched for 15 seconds, rinsed, and then gently air dried for 2 - 3 seconds. BisBlock Oxalate Dentin Desensitizer was applied (dwell time 30 seconds) and rinsed. One-Step Plus (Bisco Inc., Schaumburg, IL, USA) was applied and light cured for 10 seconds.

Group 3: Only BisBlock Oxalate Dentin Desensitizer was applied in the same manner as for Group 2.

Group 4 (control group): Neither bleaching nor desensitizer was applied.

Stainless steel premolar brackets (Generous Roth Brackets of GAC International Inc., Islandia, NY, USA) were used in this study. The avarage bracket base surface area was $12.13 \mathrm{~mm}^{2}$.

Transbond Plus self-etching primer was gently rubbed onto the surface for approximately 3 seconds with the disposable applicator. Then, a moisture-free air source was used to deliver a gentle burst of air to the enamel. Transbond XT light cure adhesive paste (3M
Unitek, Monrovia, CA, USA) was applied on the base of the bracket pad and pressed firmly onto the tooth. Excessive adhesive was removed from the periphery of the bracket base. A LED light source (Elipar Free Light 2; 3MESPE, St. Paul, MN, USA) was used for curing for 20 seconds from each of the mesial and distal sides.

After the bonding procedure, all samples were stored in deionized water at $37^{\circ} \mathrm{C}$ for 24 hours. A knife-edged shearing blade was secured on the crosshead with the direction of force parallel to the labial surface and the bracket interface. The universal test machine (Zwick Test Machine, Zwick GmbH \& Co, Ulm, Germany) was used for the SBS at a crosshead speed of 5 $\mathrm{mm} / \mathrm{min}$. Each tooth was oriented so that its facial surface was parallel to the direction of force during the SBS testing. Force was directly applied to the bracket-tooth interface. The load at bracket failure was recorded by a computer connected to the Zwick test machine. The SBS values were calculated in megapascals by dividing the force by the area of the bracket base.

After debonding, the teeth and the brackets were examined under $16 \mathrm{X}$ magnification by a stereomicroscope (Leica MS5, Leica Microsystems (SEA) Ptd Ltd., Singapore, Singapore). Any adhesive that remained after debonding was assessed and scored according to the modified adhesive remnant index (ARI). ${ }^{20}$ The ARI scale and the definition of scores are exhibited in Table 2.

Comparison among the four groups was performed by using Kruskal-Wallis rank test at the significance level of $\alpha=0.05$. Pairwise comparisons were performed by using Mann Whitney U test with Bonferroni

Table 2. The Adhesive Remnant Index (ARI) score sc $^{20}$ scale

\begin{tabular}{cl}
\hline Scores & \multicolumn{1}{c}{ Definitions } \\
\hline \hline 0 & No adhesive left on the bracket \\
1 & Less than $25 \%$ of adhesive left on the bracket \\
2 & $25-50 \%$ of adhesive left on the bracket \\
3 & $50-75 \%$ of adhesive left on the bracket \\
4 & $75-100 \%$ adhesive left on the bracket \\
5 & $100 \%$ of adhesive left on the bracket \\
\hline
\end{tabular}


Table 3. The mean shear bond strength (SBS) values (MPa), standard deviations (SD), minimum and maximum values of the groups tested (unit: MPa)

\begin{tabular}{ccccc}
\hline Groups & $\mathrm{N}$ & Mean $\pm \mathrm{SD}$ & Minimum & Maximum \\
\hline \hline Group 1 & 12 & $4.53 \pm 0.60^{\mathrm{a}}$ & 3.82 & 5.77 \\
Group 2 & 12 & $4.63 \pm 0.77^{\mathrm{a}}$ & 3.91 & 6.21 \\
Group 3 & 12 & $4.22 \pm 1.18^{\mathrm{a}}$ & 3.22 & 6.56 \\
Group 4 & 12 & $8.81 \pm 1.01^{\mathrm{b}}$ & 7.87 & 10.90 \\
\hline
\end{tabular}

Different superscript letters showed statistically different groups. Significance was determined at a probability value of $p<0.05$. Group 1, Office bleaching + self etch + bracket; Group 2, office bleaching + BisBlock + self etch + bracket; Group 3, BisBlock + self etch + bracket; Group 4, self etch + bracket (control).

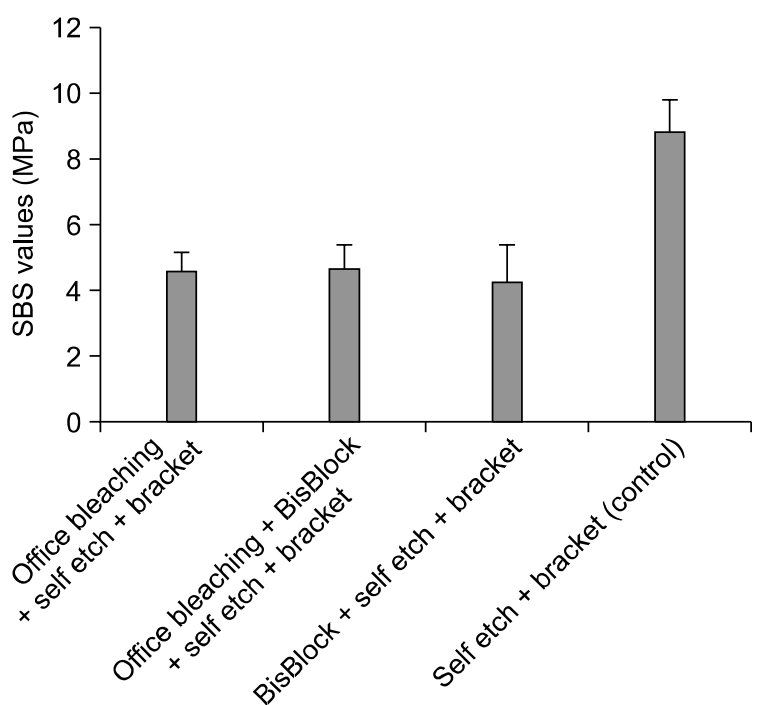

Fig 1. Schematic view of the mean shear bond strength values and standard deviations of the groups tested.

correction. ARI scores were evaluated by using Fisher's exact test to $\mathrm{m} \times \mathrm{n}$ cross tables $(p<0.05)$.

\section{RESULTS}

Descriptive statistics including the mean, standard deviation, minimum and maximum values were evaluated and shown in Table 3 and Fig 1 for each of the groups tested. On the average the control group had statistically significantly higher SBS than the treatment groups with $p=0.001$. No significant difference was found among Groups 1, 2 and 3 (Group 1-Group 2, $p$ $=0.564$; Group 1-Group 3, $p=0.371$; Group 2-Group
3, $p=0.133)$.

The frequency distribution of ARI scores among groups was presented in Table 4 and Fig 2. When all the ARI scores were compared, the control group proved to have statistically significant greater SBS than the treatment groups $(p=0.001)$ and there were no statistically significant differences between Groups 1,2 and 3 (Group 1-Group 2, $p=0.397$; Group 1-Group $3, p=0.506$; Group 2-Group 3, $p=0.909$ ). The predominant mode of failure for the treatment groups (Group 1, 2 and 3) was at the enamel-adhesive interface leaving $100 \%$ of the adhesive on the bracket base.

\section{DISCUSSION}

As more adults are now seeking orthodontic treatment, it is very important to determine whether bleaching significantly affects the bond strength of orthodontic bracket adhesives to the enamel surface. This study was performed to investigate the SBS of orthodontic brackets bonded to human enamel with a selfetching primer after bleaching, desensitizer application and combined treatment.

The adverse effects of bleaching treatment on bond strength between resin composite and tooth substrate have been reported before. ${ }^{21}$ It has been suggested that a reduction in bonding strength of resin composite in bleached teeth may be due to the presence of active chemicals from bleaching. ${ }^{22}$ Residual oxygen may be responsible for the inhibition of resin polymerization and increase in resin porosity. ${ }^{23}$ Similar to our study; Türkkahraman et al. $^{24}$ evaluated the effect of enamel bleaching on the bonding strength of orthodontic 
Table 4. The frequency distribution of Adhesive Remnant Index scores among groups

\begin{tabular}{cccccccc}
\hline Groups & $\mathrm{N}$ & Score 0 & Score 1 & Score 2 & Score 3 & Score 4 & Score 5 \\
\hline \hline Group 1 & $12^{\mathrm{a}}$ & - & - & - & - & 5 & 7 \\
Group 2 & $12^{\mathrm{a}}$ & - & - & - & - & 3 & 9 \\
Group 3 & $12^{\mathrm{a}}$ & - & - & - & 1 & 2 & 9 \\
Group 4 & $12^{\mathrm{b}}$ & - & 3 & 2 & 2 & 3 & 2 \\
\hline
\end{tabular}

Different superscript letters showed statistically different groups. Significance was determined at a probability value of $p<0.05$. Group 1, Office bleaching + self etch + bracket; Group 2, office bleaching + BisBlock + self etch + bracket; Group 3, BisBlock + self etch + bracket; Group 4, self etch + bracket (control).

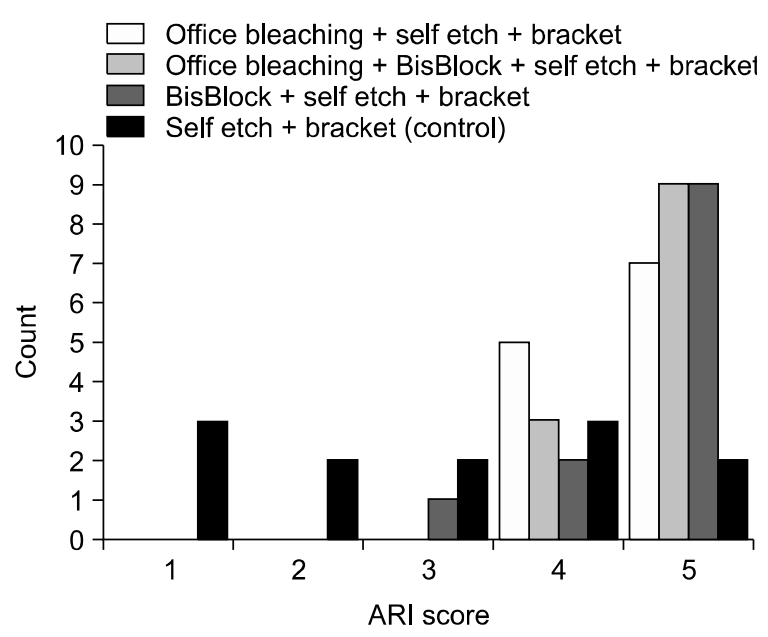

Fig 2. Schematic view of frequency distribution of Adhesive Remnant Index (ARI) scores among groups.

brackets and stated that the use of $35 \%$ hydrogen peroxide significantly decreased the bond strength of orthodontic brackets. Uysal and Sisman ${ }^{25}$ also suggested that $16 \%$ carbamide peroxide bleaching agent applied immediately before bonding significantly reduces the shear bond strength values of self-etching primer systems. Uysal et al. ${ }^{26}$ evaluated that office bleaching with $35 \%$ hydrogen peroxide did not adversely affect the bond strength of brackets bonded immediately after bleaching or for 30 days after bleaching. However, in the only study that investigated the effects of bleaching and desensitizer treatment on SBS of brackets, the SBS test was carried out immediately after the bonding procedure. $^{24}$ In our study, $15 \%$ hydrogen peroxide was used as the office bleaching treatment and showed a significantly decreased SBS of orthodontic brackets with self-etch adhesive 24 hours after bonding.

Rinsing of the enamel after application of the selfetching primer is not required. The use of a self-etching primer reduces the number of clinical steps and saves clinical operation time because separate acid etching and water rinsing steps are eliminated and application requires simply drying with air. ${ }^{27}$ Transbond Plus self-etching primer was used in this study.

It was found that optimal bond strengths can be achieved with a time delay after the bleaching. ${ }^{28}$ Sung et $\mathrm{al}^{29}$ has concluded that the use of alcohol-based bonding agents may decrease the effect on composite bond strength when restorative work is to be completed immediately after bleaching. The presence of alcohol may counteract any residual water and oxygen from the bleaching agent. ${ }^{1}$

Patients undergoing bleaching procedures may experience tooth sensitivity as a side effect. ${ }^{24}$ Orthodontists may face bonding brackets to hypersensitive teeth treated with desensitizers. The effect of desensitizers on the bond strength of adhesives to dentin is well known. It has been reported that these agents significantly affected the bond strength. ${ }^{30}$ Oxalate desensitizing materials consisting of low concentrations of oxalic acid also work well for desensitization. ${ }^{31}$ Application of oxalate materials to the exposed dentin results in precipitation of potassium oxalate or ferric oxalate crystals, occlusion of open tubules in cervical dentin, and instant sclerosis of the tubules. ${ }^{32}$ They react with calcium ions on dentin and in dentinal fluid to form insoluble calcium oxalate crystals. ${ }^{33}$ However, these crystals are either partially dissolved in oral fluids or lost during toothbrushing. ${ }^{34}$ In contrast with other ox- 
alate desensitizers, BisBlock's patented technique is unique because it incorporates the total-etch procedure prior to oxalate and adhesive placement. ${ }^{35}$ A similar study was conducted by Türkkahraman and Adanir ${ }^{12}$ who reported that orthodontic brackets bonded to enamel treated with potassium nitrate (UltraEZ) and oxalate desensitizers (BisBlock) exhibited significantly lower bond strengths than did brackets bonded to untreated enamel. Türkkahraman et al. ${ }^{24}$ found that desensitizer application significantly effected SBS of orthodontic brackets on human enamel.

Reynolds ${ }^{36}$ suggested that a minimum bond strength of 6 to $8 \mathrm{MPa}$ is adequate for most clinical orthodontic routine clinical use. In the present study, only the control group presented the average SBS value of 8.81 $\mathrm{MPa}$. Other experimental groups exhibited SBS values below $6 \mathrm{MPa}$.

A modified ARI has been developed to quantify the amount of adhesive that remains on the bracket after a bracket base debonds. ${ }^{20}$ The treatment groups exhibited higher ARI scores, often showing 100\% adhesive on the brackets than the control group, which had significantly less adhesive remaining on the bracket.

As there are various materials and application procedures, further studies are needed in order to define the effect of bleaching, desensitizer application and combined treatment on SBS of orthodontic brackets bonded to human enamel with a self-etching primer. Further studies should investigate the role of longer time periods between bleaching and desensitizer treatment and orthodontic treatment on the SBS of the brackets.

\section{CONCLUSION}

Within the limitations of this in vitro study, we conclude that:

Bleaching and desensitizer treatment significantly reduced bond strength of orthodontic brackets on human enamel with a self-etching primer after 24 hours. It is recommended that bleaching and desensitizer treatment should be postponed until the completion of orthodontic treatment. If it is determined that the patient has a bleaching history prior to applying for orthodontic treatment, the time of bleaching treatment should be established and the orthodontic treatment should be postponed sufficiently to allow for adequate bond strength of orthodontic brackets.

- 국문초록 -

미백과 탈감작제 도포 후 셀프 에칭 프라이머를 이용한 브라켓 접착 시 법랑질과 브라켓 간의 결합 강도

Nuray Attar, Yonca Korkmaz, Yasemin Kilical, Banu Saglam-Aydinatay, Ceren Ozge Bicer

본 연구는 미백, 탈감작제 도포 후, 셀프 에칭 프라이머를 이용하여 브라켓 접착 시 법랑질에 대한 전단결합강도를 비 교하기 위해 시행되었다. 48 개의 소구치를 무작위로 12 개씩 4개의 그룹으로 분류하였다. Group 1: $15 \%$ hydrogen-peroxide office bleaching agent (Illumine Office-IO), Group 2: 10 + BisBlock Oxalate Dentin-Desensitizer, Group 3: BisBlock Oxalate Dentin-Desensitizer, Group 4: 아무것도 하 지 않음(대조군). 브라켓 접착 24시간 후 전단결합강도를 측 정하였으며, 만능시험기의 속도를 $5 \mathrm{~mm} / \mathrm{min}$ 로 하여 브라켓 이 탈락할 때까지 시행하였다. Modified adhesive remnant index를 이용하여 탈락 양상을 분석하였다. 미백만 시행, 미 백과 탈감작제 도포, 탈감작제만 도포한 경우 모두 브라켓의 전단결합강도를 현저히 감소시켰으며 $(p=0.001)$, 이 세 실 험군 간에는 통계적으로 유의성 있는 차이를 관찰할 수 없었 다 (Group 1-Group 2, $p=0.564$; Group 1-Group 3, $p=$ 0.371 ; Group 2-Group 3, $p=0.133$ ). 세 실험군에서 브라켓 의 탈락은 주로 법랑질-접착제 계면에서 발생하여 브라켓 베 이스에 접착제의 $100 \%$ 가 남아있었다. 따라서 미백과 탈감 작제 도포는 교정치료 후에 시행하는 것이 바람직하다.

주요 단어: 브라켓, 접착제, 접착

\section{REFERENCES}

1. Shinohara MS, Peris AR, Rodrigues JA, Pimenta LA, Ambrosano GM. The effect of nonvital bleaching on the shear bond strength of composite resin using three adhesive systems. J Adhes Dent 2004;6:205-9.

2. Unlu N, Cobankara FK, Ozer F. Effect of elapsed time following bleaching on the shear bond strength of composite resin to enamel. J Biomed Mater Res B Appl Biomater 2008;84:363-8.

3. Marshall MV, Cancro LP, Fischman SL. Hydrogen peroxide: a review of its use in dentistry. J Periodontol 1995;66:786-96.

4. Leonard RH Jr, Austin SM, Haywood VB, Bentley CD. Change in $\mathrm{pH}$ of plaque and $10 \%$ carbamide peroxide solution 
during nightguard vital bleaching treatment. Quintessence Int 1994;25:819-23.

5. Josey AL, Meyers IA, Romaniuk K, Symons AL. The effect of a vital bleaching technique on enamel surface morphology and the bonding of composite resin to enamel. J Oral Rehabil 1996;23:244-50.

6. Gürgan S, Bolay S, Alaçam R. In vitro adherence of bacteria to bleached or unbleached enamel surfaces. J Oral Rehabil 1997;24:624-7.

7. Canay S, Cehreli MC. The effect of current bleaching agents on the color of light-polymerized composites in vitro. J Prosthet Dent 2003;89:474-8.

8. Crim GA. Post-operative bleaching: effect on microleakage. Am J Dent 1992;5:109-12.

9. Perdigão J, Francci C, Swift EJ Jr, Ambrose WW, Lopes M. Ultra-morphological study of the interaction of dental adhesives with carbamide peroxide-bleached enamel. Am J Dent 1998;11:291-301.

10. Holland GR, Narhi MN, Addy M, Gangarosa L, Orchardson R. Guidelines for the design and conduct of clinical trials on dentine hypersensitivity. J Clin Periodontol 1997;24:808-13.

11. Walters PA. Dentinal hypersensitivity: a review. J Contemp Dent Pract 2005;6:107-17.

12. Türkkahraman H, Adanir N. Effects of potassium nitrate and oxalate desensitizer agents on shear bond strengths of orthodontic brackets. Angle Orthod 2007;77:1096-100.

13. Watanabe I, Nakabayashi N, Pashley DH. Bonding to ground dentin by a phenyl-P self-etching primer. J Dent Res 1994; 73:1212-20.

14. Frankenberger R, Perdigão J, Rosa BT, Lopes M. "No-bottle" vs "multi-bottle" dentin adhesives--a microtensile bond strength and morphological study. Dent Mater 2001;17:373-80.

15. Van Meerbeek B, De Munck J, Yoshida Y, Inoue S, Vargas $\mathrm{M}$, Vijay $\mathrm{P}$, et al. Buonocore memorial lecture. Adhesion to enamel and dentin: current status and future challenges. Oper Dent 2003;28:215-35.

16. Perdigão J, Geraldeli S, Hodges JS. Total-etch versus self-etch adhesive: effect on postoperative sensitivity. J Am Dent Assoc 2003;134:1621-9.

17. Attar N, Korkmaz Y. Effect of two light-emitting diode (LED) and one halogen curing light on the microleakage of Class $\mathrm{V}$ flowable composite restorations. J Contemp Dent Pract 2007; 8:80-8.

18. Gokcelik A, Ozel Y, Ozel E, Arhun N, Attar N, Firatli S, et al. The influence of Er:YAG laser conditioning versus self-etching adhesives with acid etching on the shear bond strength of orthodontic brackets. Photomed Laser Surg 2007; 25:508-12.

19. Miller RA. Laboratory and clinical evaluation of a self-etching primer. J Clin Orthod 2001;35:42-5.

20. Oliver RG. The effect of different methods of bracket removal on the amount of residual adhesive. Am J Orthod Dentofacial Orthop 1988;93:196-200.

21. Lai SC, Tay FR, Cheung GS, Mak YF, Carvalho RM, Wei SH, et al. Reversal of compromised bonding in bleached enamel. J Dent Res 2002;81:477-81.

22. Lai SC, Mak YF, Cheung GS, Osorio R, Toledano M, Carvalho RM, et al. Reversal of compromised bonding to oxidized etched dentin. J Dent Res 2001;80:1919-24.

23. Titley KC, Torneck CD, Smith DC, Adibfar A. Adhesion of composite resin to bleached and unbleached bovine enamel. J Dent Res 1988;67:1523-8.

24. Türkkahraman H, Adanir N, Güngör AY. Bleaching and desensitizer application effects on shear bond strengths of orthodontic brackets. Angle Orthod 2007;77:489-93.

25. Uysal T, Sisman A. Can previously bleached teeth be bonded safely using self-etching primer systems? Angle Orthod 2008; 78:711-5.

26. Uysal T, Basciftci FA, Uşümez S, Sari Z, Buyukerkmen A. Can previously bleached teeth be bonded safely? Am J Orthod Dentofacial Orthop 2003;123:628-32.

27. Eminkahyagil N, Korkmaz Y, Gokalp S, Baseren M. Shear bond strength of orthodontic brackets with newly developed antibacterial self etch adhesive. Angle Orthod 2005;75:843-8.

28. Cavalli V, Reis AF, Giannini M, Ambrosano GM. The effect of elapsed time following bleaching on enamel bond strength of resin composite. Oper Dent 2001;26:597-602.

29. Sung EC, Chan SM, Mito R, Caputo AA. Effect of carbamide peroxide bleaching on the shear bond strength of composite to dental bonding agent enhanced enamel. J Prosthet Dent 1999;82:595-9.

30. Aranha AC, Siqueira Junior Ade S, Cavalcante LM, Pimenta LA, Marchi GM. Microtensile bond strengths of composite to dentin treated with desensitizer products. J Adhes Dent 2006;8:85-90.

31. Pashley DH. Dentin permeability, dentin sensitivity, and treatment through tubule occlusion. J Endod 1986;12:465-74.

32. Camps J, Pashley D. In vivo sensitivity of human root dentin to air blast and scratching. J Periodontol 2003;74:1589-94.

33. Gillam DG, Mordan NJ, Sinodinou AD, Tang JY, Knowles JC, Gibson IR. The effects of oxalate-containing products on the exposed dentine surface: an SEM investigation. J Oral Rehabil 2001;28:1037-44.

34. Gillam DG, Khan N, Mordan NJ, Barber PM. Scanning electron microscopy (SEM) investigation of selected desensitizing agents in the dentine disc model. Endod Dent Traumatol 1999;15:198-204.

35. Tay FR, Pashley DH, Mak YF, Carvalho RM, Lai SC, Suh BI. Integrating oxalate desensitizers with total-etch two-step adhesive. J Dent Res 2003;82:703-7.

36. Reynolds IR. A review of direct orthodontic bonding. Br J Orthod 1975;2:171-8. 